\title{
Biodegradation by composting of municipal organic solid waste into organic fertilizer using the black soldier fly (Hermetia illucens) (Diptera: Stratiomyidae) larvae
}

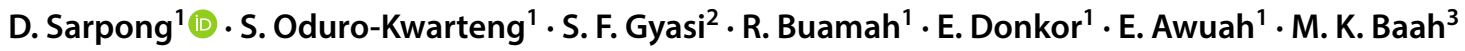

Received: 16 April 2018 / Accepted: 16 April 2019 / Published online: 3 May 2019

(C) The Author(s) 2019

\begin{abstract}
Purpose The objectives of this study were to assess the black soldier fly larvae (BSFL) composting potential and to analyse the quality of organic fertilizer produced for agricultural purposes.

Methods The waste biodegradation was determined by varying waste feed treatment $(2,2.5,3.0,3.5$, to $4 \mathrm{~kg})$ and control treatment of ( $2 \mathrm{~kg}$ ) of heterogeneous mixture of municipal organic solid waste from market, restaurant and households. Each of the setups received equal number of viable larvae (i.e. 2000) which were 5-6 days old. To analyse the nutrient concentration of the compost residues with BSFL, the substrate and final compost were evaluated based on the levels of NPK as well as the C:N ratio. To evaluate the toxic levels of the final compost in terms of heavy metals, the presence and levels of As, $\mathrm{Cd}, \mathrm{Fe}, \mathrm{Pb}$ and $\mathrm{Ni}$ were investigated.

Results The analysis showed that there was high percentage increase of nitrogen, phosphorus and potassium levels, i.e. $41.2 \%$ ( $\mathrm{SD} \pm 0.71 \%$ ), 32.4\% ( $\mathrm{SE} \pm 0.2 \%$ ) and $77.1 \%$ ( $\mathrm{SE} \pm 0.19 \%$ ), respectively. It was found that the larvae degraded more than half of the total substrate within 2 weeks. The study showed a decrease in heavy metal concentrations after larvae composting. Conclusion The study revealed that the concentration of NPK increased significantly among the treatment groups. The study further revealed that some of the heavy metals under investigation had reduced to an acceptable level according to the standards of both local and international regulatory bodies.
\end{abstract}

Keywords Municipal organic solid waste $\cdot$ Biodegradation $\cdot$ Black soldier fly larvae $\cdot$ Organic fertilizer and heavy metal

\section{Introduction}

Municipal solid waste management is an issue of great concern to especially urban governance because of solid waste effects on the environmental health most especially in the developing countries (UN-HABITAT 2010). This is due to inadequate infrastructure and technical inefficiencies. The impact on poor environmental sanitation and solid waste in the cities and towns could threaten nation's development (Sarkar and Chourasia 2017). In the year 2016, about 50\%

D. Sarpong

dsarpong2001@yahoo.com

1 Department of Civil Engineering, Kwame Nkrumah University of Science and Technology, Kumasi, Ghana

2 Department of Basic and Applied Biology, University of Energy and Natural Resources, Sunyani, Ghana

3 AMP Logistics, Tema, Ghana of the world population lived in cities and generate more than 3 million metric tons of waste (including, household items, food waste, and packaging) on a daily basis. By the year 2025, this number will double (Hoornweg and BhadaTata 2012).

A report by FAO estimated that 1.6 billion tons of food waste were generated worldwide in 2007 and that accounted for about one-third of the global food production. This waste occurred at all stages from production to consumption. In addition, improper disposal of solid waste takes up space in landfills. This eventually contributes to the spread of disease, and the production of noxious odour (Hoornweg and BhadaTata 2012). It is also reported that food waste is the number three contributor of global carbon dioxide production and produces more than double the carbon dioxide produced by all ground transportation in the United States of America.

In the year 2012, globally, solid waste management costs approximately $\$ 205.4$ billion and it is expected to increase to about $\$ 375.5$ billion in 2025 (Hoornweg and Bhada-Tata 
2012). In the cities and towns, uncollected solid waste contributes to flooding, air pollutions, and public health impact such as respiratory ailment, diarrhoea, and dengue fever (Barry 2004).

There are several naturally occurring microorganisms that can convert organic waste into valuable resources such as nitrogen, phosphorus and potassium which are useful to plants. A typical example is the use of worms to degrade waste.

Vermicomposting is an aerobic process of organic waste degradation and stabilization by interaction of microorganisms and earthworms under controlled conditions (Dominguez and Edwards 2011).Vermicomposting is not known to be a widespread approach to urban waste management in low- and middle-income countries (Diener et al. 2011). The expected barriers to vermicomposting are the large space requirement, poor supporting policies and measures from government and low revenue to sustain its operation (Mainoo 2007; Dominguez and Edwards 2011).

For several years, researchers globally have proposed using the larvae of black soldier fly (Hermetia illucens) (Diptera: Stratiomyidae) as a potential means to degrade organic matter such as food waste to divert the materials away from the limited landfills (Diener et al. 2011; Gabler and Vinnerås 2014). The black soldier fly (BSF) is a wasplike fly distributed over the tropical and temperate regions of the world (Sarpong et al. 2018). The insect is native to America but through human-mediated dispersal, now they are found almost all over the world (Rana 2014; Tomberlin et al. 2002; Sarpong et al. 2018).

The uniqueness of the insect, black soldier fly, is their ability to successfully colonize a wide variety of resources ranging from swine manure (Alvarez 2012), animal remains (Wang and Shelomi 2017). It has been reported that the BSF larvae are capable of degrading human faeces (Lalander et al. 2013; Banks et al. 2014) and animal faeces (Charlton et al. 2015). Past researchers have established that many insects could be selective with regard to what and how much waste they can consume (Cammack and Tomberlin 2017).

The aforementioned studies used either homogeneous agricultural, livestock manure or human faeces and vegetable waste as feedstock. Black soldier fly larvae application to treat unshredded feeding sources of municipal organic solid waste is yet to be fully understood and proven. In addition, limited literature exists on the use of black soldier fly larva's ability to remove heavy metals from heterogeneous organic fraction of municipal organic solid waste (OFMSW) to be considered as safe organic compost.

Once these facts are well established, organic waste from municipalities could be manipulated to optimize waste reduction and composting materials into valuable products. In view of the above, the objectives of the study are to (1) investigate the decomposition efficiency of the black soldier fly larvae on heterogeneous mixture of municipal organic solid waste, (2) assess the larvae compost maturity and (3) analyse the heavy metal removal of the compost for agricultural purposes.

\section{Materials and methods}

\section{Study site}

The research study site was located in the campus of the Kwame Nkrumah University of Science and Technology (Civil Engineering Department) in Kumasi, Ghana. The experiment was carried out under a constructed shelter $(45 \times 10 \mathrm{~m})$ roof of corrugated metal sheet and enclosed by mosquito nets.

\section{Black soldier fly colony}

A population of black soldier fly (Hermetia illucens) (Diptera: Stratiomyidae) was attracted from the natural ecosystem and kept in five different cages of size $(60 \times 60 \times 45 \mathrm{~cm}$ each), covered with transparent mosquito nylon net. The cages were placed on top of a table $(0.5 \mathrm{~m}$ height), exposed daily to direct sunlight for approximately $12 \mathrm{~h}$. In the cages, transparent plastic bows $(10 \mathrm{~L})$ containing organic waste were used to attract the BSF females for oviposition.

A pre-feed placed inside a plastic bowl was covered with perforated black polytene to prevent direct exposure to sunlight and loss of excessive moisture. The hatched eggs remained in the pre-feed for 4 days. The young larvae (4-6 days old) were collected and counted manually at 2-day interval for a week. The hatched larvae were kept in a container, with wetted restaurant waste as pre-feedstock under the prevailing temperature of $25.5-26.8{ }^{\circ} \mathrm{C}$ and relative humidity at $60-85 \%$. To supply the colony of new adult, 300 adult black soldier flies were attracted to the system and the same procedure was followed as described above.

\section{Experimental setup}

The larvae composting experiments were conducted in plastic containers $(41 \times 69 \mathrm{~cm} ; \varnothing \times \mathrm{h})(75 \mathrm{~L}$ capacity) (Fig. 1$)$. A drain tap was fixed at the bottom side ( $2 \mathrm{~cm}$ height) of the container. The top lid of the containers was perforated (hole dia. $10 \mathrm{~mm}$ ) to improve aeration in the system. No ramp was provided to prevent the escape of the prepupae, so that they remain in the residue. To avoid invasion of predators such as ants, reptiles and birds, the containers were mounted on top of a table, made of wood at a height of $0.5 \mathrm{~m}$. To avoid other insects from breeding, each plastic container (biodigester) was covered thoroughly with mosquito nets, prior to covering them with lids. 


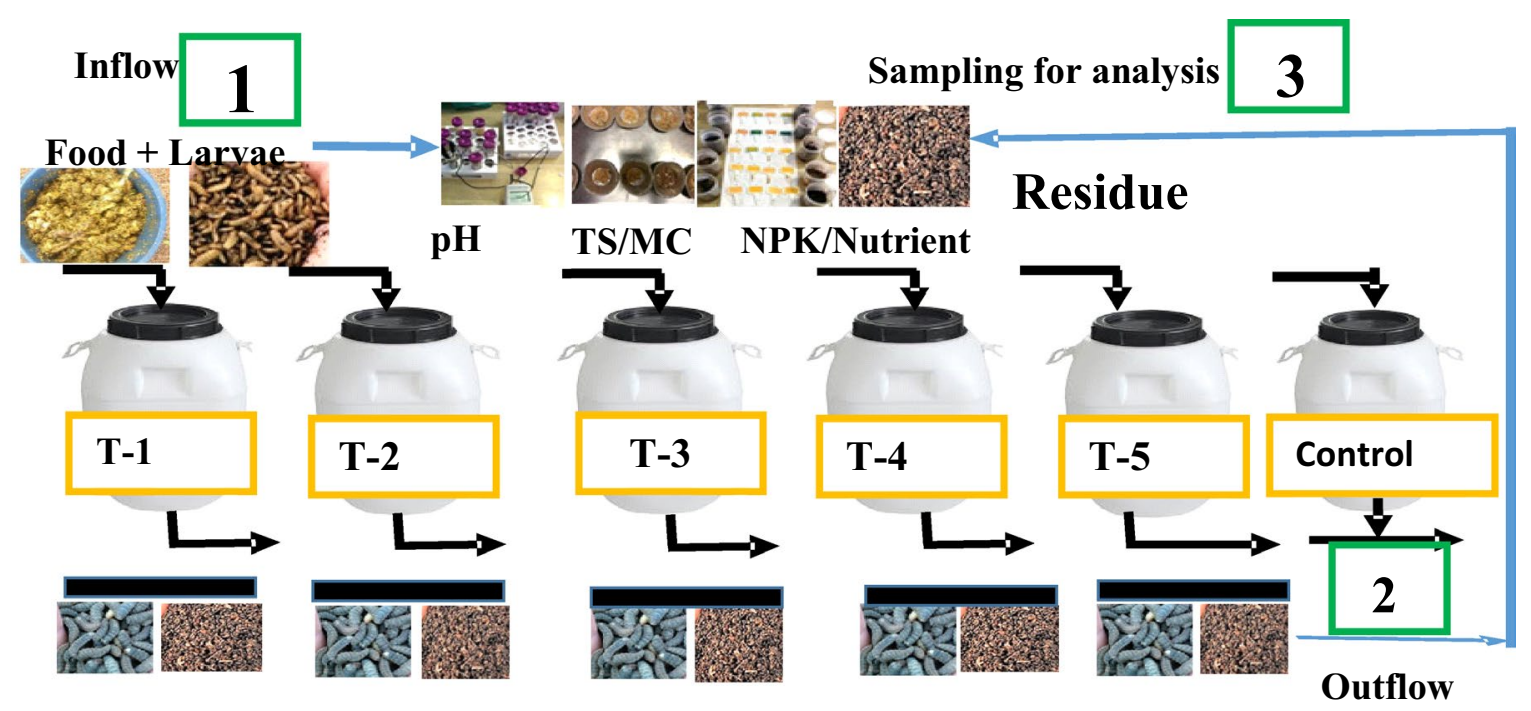

Fig. 1 Experimental setup of the BSF larvae composting

Municipal organic solid wastes from domestic, markets and restaurant in the towns near the University were used for the experiments. A bucket full of unshredded organic wastes weighing about $30 \mathrm{~kg}$ was collected daily. They were mixed thoroughly using ordinary ladle to attain certain homogeneity and then added to the designed containers $(75 \mathrm{~L})$ with varying amount of organic waste ranging from $2,2.5,3,3.5$ and $4 \mathrm{~kg}$. The feeding rates (FR) $71 \mathrm{mg} / \mathrm{larvae} /$ day, $89 \mathrm{mg} /$ larvae/day, $107 \mathrm{mg} /$ larvae/day, $125 \mathrm{mg} / \mathrm{larvae} /$ day to $143 \mathrm{mg} / \mathrm{larvae} /$ day and a control $(2 \mathrm{~kg})$, which is represented as T-1, T-2, T-3, T-4, T-5 and $T-c$, respectively, were established. The feeding rate (FR) was expressed as the total amount of organic waste given to 2000 number of larvae over a period of 14 days, taking into account the life cycle of the black soldier fly. In addition to the substrate in the containers, each of the five experimental containers was inoculated with 20005 -day-old larvae and each larvae weighed approximately $0.03 \mathrm{mg}$. The 6th container received $2 \mathrm{~kg}$ of homogenate without larvae (natural compost without larvae) and it served as a control for the analysis.

To ensure a coequal establishment of the larvae population, all the five experimental setups and the control (degradation without larvae) were fed at once (i.e. batch system). In total, $15 \mathrm{~kg}$ of fresh and untreated organic solid waste was given to 10,000 larvae. The system was monitored continuously for a period of 14 days according to the life cycle of the BSF. At the starting phase, fresh food wastes were placed at the bottom and then the larvae were placed on top of the waste materials. The feeding rates were maintained for repeated experiment, five times over a period of 108 weeks. Samples of organic solid waste and residue were collected for further analysis on total organic carbon (TOC), total nitrogen (TN), total phosphorus (TP), and total potassium (TK).

The nitrogen contents were investigated utilizing the Kjeldahl method as clarified in the Swedish Standard, SS-EN 13342. The phosphorus contents were investigated utilizing the ISO 11466 (Soil quality-Extraction of trace solvent in water regia). The potassium contents were broken down utilizing ICP-AES spectrophotometry and a mix of ISO 11466 (Soil quality-Extraction of trace elements dissolvable in water regia). Heavy metals ( $\mathrm{As}, \mathrm{Ni}, \mathrm{Cd}, \mathrm{Pb}, \mathrm{Fe}$ ) were also analysed. The temperature, $\mathrm{pH}$ and moisture contents of the substrate were also investigated. Trace elements and phosphorus were determined using water regia extraction strategy and AES spectrophotometry. The TOC was determined by total organic carbon analyser.

Due to limited funding, the scope of the research did not consider the final utilization of the prepupae for agricultural purposes. The aquaculture and agronomical aspects of the end product would be of great interest and it would be considered in the near future.

\section{Statistical analysis}

Linear regression and one-way analysis of variance (ANOVA) with subsequent Tukey HSD test were conducted to establish relations and difference between the various treatments $(P<0.05)$. An increase in nutrient concentration of the treatment groups was calculated according to the formula (residue - substrate)/substrate. 


\section{Results and discussion}

\section{Physiochemical characteristics of the substrate and compost}

The temperature of the substrate ranges from 26.0 to $26.7^{\circ} \mathrm{C}$ with a mean value of $26.4{ }^{\circ} \mathrm{C}$. The lowest temperature of the residue ranges from 24.2 to $24.7^{\circ} \mathrm{C}$, with mean value of 24.5 ${ }^{\circ} \mathrm{C}$, while the highest temperature ranges from 26.3 to 26.7 ${ }^{\circ} \mathrm{C}$ with mean value of $26.5{ }^{\circ} \mathrm{C}$. The results also showed a temperature range from 25.7 to $25.8^{\circ} \mathrm{C}$, with a mean value of $25.8{ }^{\circ} \mathrm{C}$ for the control (Table 1 ).

The $\mathrm{pH}$ of the substrate ranges from 5.05 to 5.51, with mean value of 5.3. After 14 days of larvae composting, the lowest $\mathrm{pH}$ recorded ranges from 7.04 to 7.51 , with mean value of 7.3. However, the highest $\mathrm{pH}$ ranges from 7.02 to 7.72 , with mean value of 7.4 as shown in Table 1 . The study also reported a pH range of 6.04-6.31, with a mean value of 6.2 for the control treatment group.

The $\mathrm{pH}$ of the substratum was acidic in the feedstock. An increase in $\mathrm{pH}$ was in line with observations made by other researchers (Verma 2002; Diener et al. 2011). Earlier authors fed the larvae of black soldier fly with chicken manure and pig manure and this was consistent with our study. An increase in the $\mathrm{pH}$ values was associated with curing of compost (Wei et al. 2007; Bernal et al. 2009).

The dark brown colour of the final compost could be due to the presence of oxygen and stability. It has been reported that the appearance of a dark brown colour and earthly aromatic flavour in compost often shows its maturity (Bernal et al. 2009; Diener et al. 2011).

The moisture contents of the substrate and the residue were measured (Table 1). The study showed that the highest and the lowest moisture contents of the substrate were $63.1 \%$ and $60.3 \%$, respectively, while the mean value amounted to $62.7 \%$. The lowest mean moisture content of the residue was $62.7 \%$, while the highest mean moisture content of the residue was $64.9 \%$.

A high moisture content ( $\geq 60 \%$ ) of compost usually required post-treatment such as further drying. Post-treatment with thermophilic aerobic composting usually leads to a reduction in the volume of feed (Aja and Al-Kayiem 2014). The temperature of the composting was mesophilic. Aeration was improved on the compost system as a result of the movement and natural turning of the waste by the larvae. Other researchers have reported that high temperature (i.e. $45^{\circ} \mathrm{C}$ or more) could cut down the pathogenic loads of the final compost (Banks 2014; Tirado 2008; Dortmans 2015).

Moisture plays an essential role in the metabolic activities of larvae and microorganisms because it indirectly supplies oxygen (Bernal et al. 2009; Dortmans 2015). In this study, the water contents of the feedstock were adequate for decomposition. There was no observable problem except the leachate generation of the bottom of the digesters during the biodegradation processes. A moisture content of 40-60\% provides adequate water without hindering aeration. Moisture contents of $40 \%$ slow down both larvae and bacterial activities (Bernal et al. 2009). When moisture contents exceed $60 \%$, it could lead to nutrient leachate and usually results in environmental odour (Dortmans 2015).

\section{Variations in the total organic carbon, $\mathrm{C}: \mathrm{N}$ ratio and $C: P$ ratio of the substrate and residue}

\section{Total organic carbon (TOC) levels}

An analysis of the results showed that the highest mean percentage TOC removal of $21 \%$ (SD $\pm 5 \%$ ) was reported in treatment group T-3, which corresponded to the feeding rate $(\mathrm{FR})$ of $107 \mathrm{mg} / \mathrm{larvae} /$ day. The lowest percentage mean TOC reduction of $11 \%$ ( $\mathrm{SD} \pm 2 \%$ ) was measured in

Table 1 Mean values of temperature, $\mathrm{pH}$ and moisture content of the substrate and residue

\begin{tabular}{|c|c|c|c|c|c|c|}
\hline \multirow[t]{2}{*}{ Treatment regime } & \multicolumn{2}{|l|}{ Mean temp $\left({ }^{\circ} \mathrm{C}\right)$} & \multicolumn{2}{|l|}{ Mean $\mathrm{pH}$} & \multicolumn{2}{|c|}{ Mean moisture content (\%) } \\
\hline & Substrate & Residue & Substrate & Residue & Substrate & Residue \\
\hline $\mathrm{T}-1(2.0 \mathrm{~kg})$ & $26.4(26.0-26.7)$ & $24.5(24.2-24.7)$ & $5.3(5.05-5.51)$ & $7.3(7.04-7.51)$ & $61.7(60.3-63.1)$ & $62.7(60.1-65.3)$ \\
\hline $\mathrm{T}-2(2.5 \mathrm{~kg})$ & $26.4(26.0-26.7)$ & $26.3(26.1-26.5)$ & $5.3(5.05-5.51)$ & $7.3(7.10-7.51)$ & $61.7(60.3-63.1)$ & $64.5(63.2-65.7)$ \\
\hline $\mathrm{T}-3(3.0 \mathrm{~kg})$ & $26.4(26.0-26.7)$ & $26.3(26.0-26.5)$ & $5.3(5.05-5.51)$ & $7.4(7.02-7.72)$ & $61.7(60.3-63.1)$ & $64.5(63.4-65.5)$ \\
\hline $\mathrm{T}-4(3.5 \mathrm{~kg})$ & $26.4(26.0-26.7)$ & $26.4(26.1-26.6)$ & $5.3(5.05-5.51)$ & $7.4(7.12-7.61)$ & $61.7(60.3-63.1)$ & $64.5(63.4-65.5)$ \\
\hline $\mathrm{T}-5(4.0 \mathrm{~kg})$ & $26.4(26.0-26.7)$ & $26.5(26.3-26.7)$ & $5.3(5.05-5.51)$ & $7.3(7.01-7.61)$ & $61.7(60.3-63.1)$ & $64.9(64.0-65.8)$ \\
\hline $\begin{array}{r}\text { Control (without } \\
\text { larvae), } 2.0 \mathrm{~kg} \text { ) }\end{array}$ & $26.4(26.0-26.7)$ & $25.8(25.7-25.8)$ & $5.3(5.05-5.51)$ & $6.2(6.04-6.31)$ & $61.7(60.3-63.1)$ & $61.9(60.3-63.5)$ \\
\hline
\end{tabular}

Figures in parenthesis represent the range values of the respective parameters. Treatment regime values in parenthesis ranging from 2.0 to $4.0 \mathrm{~kg}$ are the initial quantities of substrate 


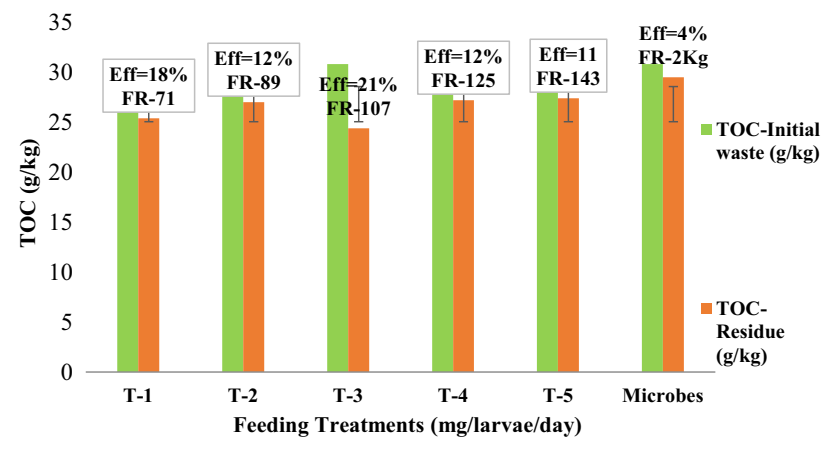

Fig. 2 Total organic carbon (TOC) of the substrate and residue

treatment group T-5, with feeding rate of $143 \mathrm{mg} / \mathrm{larvae} / \mathrm{day}$ as shown in (Fig. 2). The study further showed a reduction of TOC in the control group (i.e. natural microbes) with removal efficiency of $4 \%$ (SD $\pm 1 \%$ ). In comparing the TOC reduction efficiencies of the larvae (T-1) and control (T-c) treatment groups, it was found that the difference between TOC removal of T-1 and T-c amounts to $14 \%$ (Fig. 2) and it was statistically highly significant ( $p=0.02)$ (Fig. 2).

The reduction of TOC could be due to carbon loss in the form of $\mathrm{CO}_{2}$. It was observed that TOC removal rates increased significantly in treatment $\mathrm{T}-3$. This demonstrated that carbon used by the BSF larvae was higher than in the other treatment groups (Sarpong et al. 2018). The treatment groups T-1, T-2, T-3, T-4, T-5, and T-c were represented by feeding rates FR-71, FR-89, FR-107, FR-125, FR-143 and control (microbes), respectively. The results obtained showed that T-2 and T-4 had the same reduction efficiency of TOC but these were not as high as T-1 and T-3. So far, the control (microbial composting, T-c) did not show any statistical significant difference between reduction in TOC. This could probably be due to the fact that microbial organic waste degradation required adequate time for the microbes to multiply to be able to utilize the carbon compounds.

The utilization of carbon by BSF larvae has been reported by Diener et al. (2015) and Sarpong et al. (2018). It has also been reported that BSF larvae reduced TOC up to $62 \%$ in swine manure (Zhao et al. 2016). The loss of carbon in this study could be due to respiration of the larvae through the skin (Lin-ki 1975). It is being reported that the voracious eating habit of the larvae and its movement through the feedstock led to an increase in surface area, which eventually resulted in faster decline of TOC. This assertion was in line with results described by Dortmans (2015) and (Zhao et al. (2016).

\section{Carbon to nitrogen ratio}

The results of carbon to nitrogen ratio $(\mathrm{C}: \mathrm{N}$ ratio) reduction are shown in Fig. 3. The highest $\mathrm{C}: \mathrm{N}$ ratio reduction was from 14:1 to 8:1, which was measured in the treatment groups $\mathrm{T}-2, \mathrm{~T}-3$ and $\mathrm{T}-4$. The lowest $\mathrm{C}: \mathrm{N}$ ratio reduction was from 14:1 to 9:1, which occurred in treatment groups $\mathrm{T}-1$ and $\mathrm{T}-5$. The study also showed a reduction in $\mathrm{C}: \mathrm{N}$ ratio in the control treatment (microbes) from 12:1 to 11:1. The results obtained for final compost showed a significant difference in the $\mathrm{C}: \mathrm{N}$ ratio reduction between the larvae treatment group and the control treatment group $(p=0.04)$.

It has been reported that carbon to nitrogen ( $\mathrm{C}: \mathrm{N}$ ratio) value of 15 or below is highly preferable for agronomic purposes (Jereb 2004; Pan et al. 2012). Therefore, the results of this study (C:N ratio falls within the limit) strongly suggest that the larvae compost obtained could be used for agricultural purpose. Any compost with C:N ratio greater than 30 is likely to immobilize nitrogen if applied to soil (Bernal et al. 2009). But if C:N ratio is less than 20, then it is likely to cause mineralisation of organic nitrogen to inorganic which is suitable for plants (Pan et al. 2012).

\section{Carbon to phosphorus ratio}

The highest C:P ratio reduction reported was from $48: 1$ to 21:1, which was measured in treatment group T-4 (Fig. 4). The lowest $\mathrm{C}: \mathrm{P}$ ratio reduction was from $48: 1$ to $31: 1$, which was reported in treatment group T-1. The study also showed a reduction in C:P ratio in the control treatment group. However, the $\mathrm{C}: \mathrm{P}$ ratio reduction between the larval treatment group and the control treatment group differed significantly $(p=0.03)$ (Fig. 4).

A progressive increase in total phosphorus was observed in all the treatment regimes including the microbial composting. However, there was a high reduction in carbon that resulted in a decrease in C:P ratio. An additional supply of phosphorus will be dependent on the amount of phosphorus in the feedstock (Polprasert and Koottatep 2007). The $\mathrm{C}: \mathrm{P}$ ratio achieved in this study was within the acceptable range for organic waste. In all the treatment regimes, there was an improvement in the C:P ratio at the different feeding rates. Similar observations were made in decomposition of organic waste using earthworm species (Polprasert and

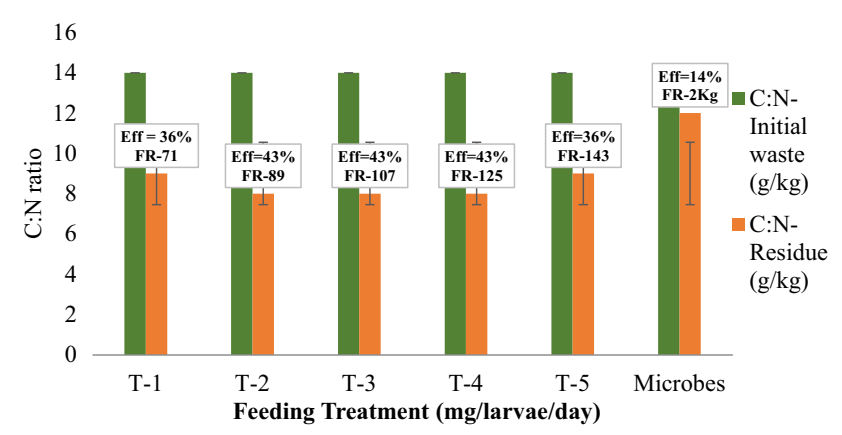

Fig. 3 Carbon:nitrogen ratio of the substrate and compost 


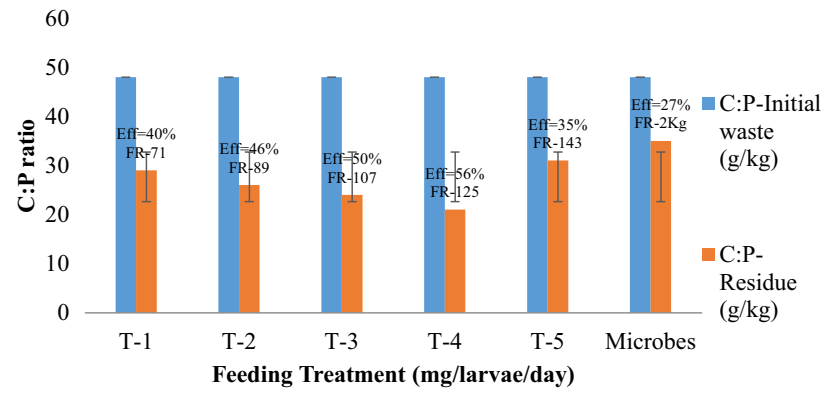

Fig. 4 Carbon:phosphorus ratio of the treatments

Koottatep 2007). A higher concentration of phosphate in compost is available during the crop-growing season. However, nutrient availability will depend on the quality of soil, the moisture contents and temperature of the environment (Pan et al. 2012).

\section{Analysis of the nutrient concentrations of the compost residues}

A percentage increase in total nitrogen (TN) was reported on the final compost (Table 2). The highest increase in total nitrogen concentration of $41 \%$ ( $\mathrm{SD} \pm 1.0 \%$ ) was reported on treatment group T-3. The lowest increase in total nitrogen concentration of $6 \%$ ( $\mathrm{SD} \pm 0.3 \%$ ) was recorded in larvae treatment group T-5, whilst the mean percentage increase in $\mathrm{TN}$ of the control was $3 \%$ ( $\mathrm{SD} \pm 0.1 \%$ ). In comparing the percentage increase in $\mathrm{TN}$, the larvae treatment group $\mathrm{T}-1$ performed higher (4\%) than the control treatment group $\mathrm{T}-\mathrm{c}$, in 14 days and it was statistically significant $(p=0.04)$.

The nitrogen concentrations increased over time, which could be due to the reduction of dry weight of organic matter (re-concentration) in the substrate by larvae decomposition. Another probable reason for this increase in nitrogen could be due to the biochemical activities of the larvae and the secretions of nitrifying bacteria from the gut of the larvae
(Bernal et al. 2009). This was in line with a study conducted by Kim et al. (2011).

\section{Total phosphorus concentration}

The study showed an increase in the concentration of total phosphorus (TP) in the organic waste composting by BSF larvae (Table 3). The highest TP reported was 32.4\% ( $\mathrm{SD} \pm$ $0.16,0.14,0.16 \%$ ) in the final compost treatment group T-1, $\mathrm{T}-2$ and $\mathrm{T}-3$, respectively. In the larvae treatment group, the lowest increase in $\mathrm{TP}$ was $17.6 \%$ ( $\mathrm{SD} \pm 0.1 \%)$, which was reported in T-5, while the control showed much lower percentage increase $(10.3 \%$; $\mathrm{SD} \pm 0.05 \%)$ in total phosphorus in the compost.

\section{Total potassium concentration}

The study showed an increased concentration in total potassium (TK) (Table 4). The highest mean percentage increase in total potassium was $77.1 \%$ ( $\mathrm{SD} \pm 0.19 \%$ ), which was reported in the treatment group T-3 and this was statistically significant $(p=0.02)$. The lowest percentage increase in TK was $42.9 \%$ ( $\mathrm{SD} \pm 0.11 \%$ ), which was reported in the treatment group T-1. Further analysis showed that a percentage increase in total potassium in the control treatment group amounted to $14.3 \%$ ( $\mathrm{SD} \pm 0.04 \%$ ),

The high percentage increase in potassium (dry weight) content in the compost reported in this current study was similar to the results found in poultry manure compost (Bernal et al. 2009). The poultry manure content of the reference study was twice as much as the ammonium in dairy manure compost of the same study.

\section{Heavy metal assessment of the compost}

The toxicological assessment of the compost with respect to arsenic levels showed that the high level of heavy metal
Table 2 Mean values of total nitrogen $(\mathrm{TN})$ in the substrate and residue

\begin{tabular}{|c|c|c|c|c|c|c|}
\hline \multirow[t]{2}{*}{ Treatment regime } & \multicolumn{2}{|c|}{$\begin{array}{l}\text { Mean total nitrogen } \\
(\mathrm{mg} / \mathrm{kg})\end{array}$} & \multirow{2}{*}{$\begin{array}{l}\text { Increase in } \\
\text { concentration } \\
(\%)\end{array}$} & \multirow{2}{*}{$\begin{array}{l}\text { Standard } \\
\text { deviation } \\
(\mathrm{SD} \pm) \%\end{array}$} & \multirow[t]{2}{*}{$\begin{array}{l}\text { Feeding rate (FR) } \\
\text { (mg/larvae/day) }\end{array}$} & \multirow[t]{2}{*}{$p$ values } \\
\hline & Substrate & Residue & & & & \\
\hline $\mathrm{T}-1(2.0 \mathrm{~kg})$ & 3.4 & 4.1 & $20.6 \mathrm{ab}$ & 0.49 & 71 & 0.03 \\
\hline $\mathrm{T}-2(2.5 \mathrm{~kg})$ & 3.4 & 4.4 & 29.4 & 0.71 & 89 & 0.07 \\
\hline $\mathrm{T}-3(3.0 \mathrm{~kg})$ & 3.4 & 4.8 & $41.2 \mathrm{ab}$ & 0.99 & 107 & 0.01 \\
\hline $\mathrm{T}-4(3.5 \mathrm{~kg})$ & 3.4 & 3.8 & 11.8 & 0.29 & 125 & 0.05 \\
\hline $\mathrm{T}-5(4.0 \mathrm{~kg})$ & 3.4 & 3.6 & 5.9 & 0.14 & 143 & 0.05 \\
\hline $\begin{array}{l}\text { Control (without } \\
\text { larvae) }(2.0 \mathrm{~kg})\end{array}$ & 3.4 & 3.5 & $2.9 \mathrm{a}$ & 0.07 & - & - \\
\hline
\end{tabular}

${ }^{\mathrm{a}, \mathrm{ab}}$ Mean value followed by the same letter in the same column varies significantly $(P<0.05)$. Treatment regime values in parenthesis ranging from 2.0 to $4.0 \mathrm{~kg}$ are the initial quantities of substrate. The feeding rate (FR) was expressed as the total amount of organic waste given to 2000 larvae over a period of 14 days 
in the substrate (approximately $0.01 \mathrm{mg} / \mathrm{kg}$ ) was maximally reduced to $0.0002 \mathrm{mg} / \mathrm{kg}$ in the final compost (Table 5). The highest arsenic removal efficiency of the system by the larvae was $98 \%$ with a standard deviation of $0.01 \%$. This was not significant in treatment groups T-2, T-3 and T-5 ( $p=$ 0.05 ) as shown in Table 5.

As part of the study, the efficiency of the larvae in reducing cadmium levels in the feedstock was analysed. The highest statistically significant cadmium efficiencies were almost $100 \%$, i.e. $99.78,99.43$ and $99.56 \%$ with standard deviations of $0.28,0.21$ and $0.14 \%$ in treatments groups $\mathrm{T}-1$, T-3 and T-4, respectively (Table 6).

With respect to the levels of $\mathrm{Fe}$ in the compost after the larvae degradation, assessment of heavy metals was investigated (Table 7). Analysis of the results showed a high concentration of $\mathrm{Fe}(5.5 \mathrm{mg} / \mathrm{kg})$ in the initial feedstock in
Table 3 Mean values of total phosphorus (TP) in the substrate and residue

Table 4 Mean values of total potassium (TK) in the substrate and residue

Table 5 Arsenic concentrations in the organic solid waste and in the compost obtained using different feeding rates $(\mathrm{mg} /$ larvae/day) for black soldier fly larvae (BSFL)

\begin{tabular}{|c|c|c|c|c|c|c|}
\hline \multirow[t]{2}{*}{ Treatment regime } & \multicolumn{2}{|c|}{$\begin{array}{l}\text { Mean total phospho- } \\
\text { rus (mg/kg) }\end{array}$} & \multirow{2}{*}{$\begin{array}{l}\text { Increase in } \\
\text { concentration } \\
(\%)\end{array}$} & \multirow{2}{*}{$\begin{array}{l}\text { Standard } \\
\text { deviation } \\
(\mathrm{SD} \pm) \%\end{array}$} & \multirow[t]{2}{*}{$\begin{array}{l}\text { Feeding rate (FR) } \\
\text { (mg/larvae/day) }\end{array}$} & \multirow[t]{2}{*}{$p$ values } \\
\hline & Substrate & Residue & & & & \\
\hline $\mathrm{T}-1(2.0 \mathrm{~kg})$ & 0.68 & 0.90 & $32.4^{\mathrm{a}}$ & 0.16 & 71 & 0.04 \\
\hline $\mathrm{T}-2(2.5 \mathrm{~kg})$ & 0.68 & 0.90 & 32.4 & 0.14 & 89 & 0.04 \\
\hline $\mathrm{T}-3(3.0 \mathrm{~kg})$ & 0.68 & 0.90 & 32.4 & 0.16 & 107 & 0.05 \\
\hline $\mathrm{T}-4(3.5 \mathrm{~kg})$ & 0.68 & 0.83 & 22.1 & 0.11 & 125 & 0.06 \\
\hline $\mathrm{T}-5(4.0 \mathrm{~kg})$ & 0.68 & 0.80 & 17.6 & 0.08 & 143 & 0.08 \\
\hline $\begin{array}{r}\text { Control (without } \\
\text { larvae) }(2.0 \mathrm{~kg})\end{array}$ & 0.68 & 0.75 & $10.3^{\mathrm{a}}$ & 0.05 & - & - \\
\hline
\end{tabular}

${ }^{a}$ Mean value followed by the same letter in the same column varies significantly $(P<0.05)$. Treatment regime values in parenthesis ranging from 2.0 to $4.0 \mathrm{~kg}$ are the initial quantities of substrate. The feeding rate (FR) was expressed as the total amount of organic waste given to 2000 larvae over a period of 14 days

\begin{tabular}{|c|c|c|c|c|c|c|}
\hline \multirow[t]{2}{*}{ Treatment regime } & \multicolumn{2}{|c|}{$\begin{array}{l}\text { Mean total potassium } \\
(\mathrm{mg} / \mathrm{kg})\end{array}$} & \multirow{2}{*}{$\begin{array}{l}\text { Increase in } \\
\text { concentration } \\
(\%)\end{array}$} & \multirow{2}{*}{$\begin{array}{l}\text { Standard } \\
\text { deviation } \\
(\mathrm{SD} \pm) \%\end{array}$} & \multirow[t]{2}{*}{$\begin{array}{l}\text { Feeding rate (FR) } \\
\text { (mg/larvae/day) }\end{array}$} & \multirow[t]{2}{*}{$p$ values } \\
\hline & Substrate & Residue & & & & \\
\hline $\mathrm{T}-1(2.0 \mathrm{~kg})$ & 0.35 & 0.50 & $42.9 \mathrm{ab}$ & 0.11 & 71 & 0.04 \\
\hline $\mathrm{T}-2(2.5 \mathrm{~kg})$ & 0.35 & 0.54 & 54.3 & 0.13 & 89 & 0.05 \\
\hline $\mathrm{T}-3(3.0 \mathrm{~kg})$ & 0.35 & 0.62 & $77.1 \mathrm{ab}$ & 0.19 & 107 & 0.01 \\
\hline $\mathrm{T}-4(3.5 \mathrm{~kg})$ & 0.35 & 0.61 & 74.3 & 0.18 & 125 & 0.05 \\
\hline $\mathrm{T}-5(4.0 \mathrm{~kg})$ & 0.35 & 0.55 & 57.1 & 0.14 & 143 & 0.05 \\
\hline $\begin{array}{l}\text { Control (without } \\
\text { larvae), } 2.0 \mathrm{~kg} \text { ) }\end{array}$ & 0.35 & 0.40 & $14.3 \mathrm{a}$ & 0.04 & - & - \\
\hline
\end{tabular}

${ }^{\mathrm{a}, \mathrm{ab}}$ Mean value followed by the same letter in the same column varies significantly $(P<0.05)$. Treatment regime values in parenthesis ranging from 2.0 to $4.0 \mathrm{~kg}$ are the initial quantities of substrate. The feeding rate (FR) was expressed as the total amount of organic waste given to 2000 larvae over a period of 14 days

\begin{tabular}{|c|c|c|c|c|c|c|}
\hline \multirow[t]{2}{*}{ Treatment regime } & \multicolumn{2}{|c|}{ Mean arsenic $(\mathrm{mg} / \mathrm{kg})$} & \multirow{2}{*}{$\begin{array}{l}\text { Removal } \\
\text { efficiency } \\
(\%)\end{array}$} & \multirow{2}{*}{$\begin{array}{l}\text { Standard devia- } \\
\text { tion }(\mathrm{SD} \pm) \%\end{array}$} & \multirow{2}{*}{$\begin{array}{l}\text { Feeding rate }(\mathrm{FR}) \\
(\mathrm{mg} / \mathrm{larvae} / \text { day })\end{array}$} & \multirow[t]{2}{*}{$p$ values } \\
\hline & Substrate & Residue & & & & \\
\hline $\mathrm{T}-1(2.0 \mathrm{~kg})$ & 0.0105 & 0.0008 & 92.4 & \pm 0.01 & 71 & 0.06 \\
\hline $\mathrm{T}-2(2.5 \mathrm{~kg})$ & 0.0099 & 0.0003 & 97.0 & \pm 0.01 & 89 & 0.05 \\
\hline $\mathrm{T}-3(3.0 \mathrm{~kg})$ & 0.0100 & 0.0002 & 98.0 & \pm 0.01 & 107 & 0.05 \\
\hline $\mathrm{T}-4(3.5 \mathrm{~kg})$ & 0.0100 & 0.0008 & 92.0 & \pm 0.01 & 125 & 0.06 \\
\hline $\mathrm{T}-5(4.0 \mathrm{~kg})$ & 0.0105 & 0.0005 & 95.2 & \pm 0.01 & 143 & 0.05 \\
\hline $\begin{array}{r}\text { Control (without } \\
\text { larvae), } 2.0 \mathrm{~kg} \text { ) }\end{array}$ & 0.0110 & 0.0100 & 9.1 & \pm 0.01 & - & - \\
\hline
\end{tabular}

Treatment regime values in parenthesis ranging from 2.0 to $4.0 \mathrm{~kg}$ are the initial quantities of substrate. Values with $(P<0.05)$ were significantly different. The feeding rate $(\mathrm{FR})$ was expressed as the total amount of organic waste given to 2000 larvae over a period of 14 days 
treatment group T-1 and this was significantly $(p=0.04)$ reduced to $1.7 \mathrm{mg} / \mathrm{kg}$ (i.e. $69 \%$ ) in the final compost as shown in Table 7. The Fe removal efficiency in the control group from 5.6 to $4.66 \mathrm{mg} / \mathrm{kg}$ amounted to $17 \%$.

The concentration of nickel, a heavy metal in both the feedstock and the final compost, was analysed as part of this study. There was virtually no observable nickel removal (from 0.3 to $0.3 \mathrm{mg} / \mathrm{kg}$ and from 0.01 to $0.01 \mathrm{mg} / \mathrm{kg}$, depending on the treatments) by the larvae. The lead concentrations in the compost were also analysed to find out the extent of lead removal of the compost. The concentrations of lead $(\mathrm{Pb})$ in the substrate range from 0.01 to $0.02 \mathrm{mg} / \mathrm{kg}$, with mean value of $0.015 \mathrm{mg} / \mathrm{kg}$ (Table 8).

The lowest mean removal efficiency of lead was $80 \%$ (SD $\pm 1.6 \%$ ), which was measured in larvae treatment group T-4. The highest mean removal efficiency of lead was $90 \%$, which happened to T-1, T2, T3 and T 5 with standard deviation of $\pm 6.6, \pm 2.4, \pm 2.9$ and $\pm 2.4 \%$ respectively. The mean removal efficiency of lead in the control group was $5 \%$ (SD $\pm 1.6 \%$ ).

The study showed a decrease in heavy metal concentration after larvae degradation. This might be due to the fact that the larvae could biologically accumulate heavy metals in their tissues. Heavy metals may have been accumulated in the larvae's tissues through two different methods: first, through direct skin contact with the nutrients dissolved in the waste; second, through the digestion of certain elements dissolved in the waste after absorption through the intestine. A similar report gave an account, where earthworm's skin absorbed heavy metals in vermicomposting.

A report by Deborah and Raj (2016) has revealed about $50 \%$ reduction in cadmium levels when BSFL was fed with feedstock spiked with a known concentration of this heavy metal. It has been reported by Diener and a group of researchers that when the prepupae were homogenized and assessed for the presence of cadmium, the levels had reduced by further $50 \%$ before they emerged as flies. The reason for this reduction was due to the fact that the larvae might have discharged the heavy metals through defecation (Zurbrügg 2015).

An effective elimination of heavy metals by defecation has also been reported in larvae of the social paper wasp (Polistes dominulus) (Diener et al. 2011). However, even if the heavy metal accumulates in the cells lining of the alimentary canal, they may be ejected after a short time (Zurbrügg 2015). For instance, Tenebrio molitor (Coleoptera
Table 6 Cadmium $(\mathrm{Cd})$ concentrations in the organic solid waste and in the compost obtained using different feeding rates (mg/larvae/day) for black soldier fly larvae (BSFL)

\begin{tabular}{|c|c|c|c|c|c|c|}
\hline \multirow[t]{2}{*}{ Treatment regime } & \multicolumn{2}{|c|}{$\begin{array}{l}\text { Mean cadmium (mg/ } \\
\mathrm{kg} \text { ) }\end{array}$} & \multirow{2}{*}{$\begin{array}{l}\text { Removal } \\
\text { efficiency } \\
(\%)\end{array}$} & \multirow[t]{2}{*}{$\begin{array}{l}\text { Standard devia- } \\
\text { tion }(\mathrm{SD} \pm) \%\end{array}$} & \multirow[t]{2}{*}{$\begin{array}{l}\text { Feeding rate (FR) } \\
\text { (mg/larvae/day) }\end{array}$} & \multirow[t]{2}{*}{$p$ values } \\
\hline & Substrate & Residue & & & & \\
\hline $\mathrm{T}-1(2.0 \mathrm{~kg})$ & 0.4000 & 0.00089 & 99.78 & \pm 0.28 & 71 & 0.04 \\
\hline $\mathrm{T}-2(2.5 \mathrm{~kg})$ & 0.6000 & 0.00029 & 99.95 & \pm 0.42 & 89 & 0.06 \\
\hline $\mathrm{T}-3(3.0 \mathrm{~kg})$ & 0.3000 & 0.00170 & 99.43 & \pm 0.21 & 105 & 0.04 \\
\hline $\mathrm{T}-4(3.5 \mathrm{~kg})$ & 0.2000 & 0.00089 & 99.56 & \pm 0.14 & 125 & 0.04 \\
\hline $\mathrm{T}-5(4.0 \mathrm{~kg})$ & 0.2000 & 0.00049 & 99.75 & \pm 0.14 & 143 & 0.06 \\
\hline $\begin{array}{l}\text { Control (without } \\
\text { larvae), } 2.0 \mathrm{~kg} \text { ) }\end{array}$ & 0.1000 & 0.09010 & 9.90 & \pm 0.01 & - & - \\
\hline
\end{tabular}

Treatment regime values in parenthesis ranging from 2.0 to $4.0 \mathrm{~kg}$ are the initial quantities of substrate. Values with $(P<0.05)$ were significantly different. The feeding rate $(\mathrm{FR})$ was expressed as the total amount of organic waste given to 2000 larvae over a period of 14 days

Table 7 Iron (Fe) concentrations in the organic solid waste and in the compost obtained using different feeding rates (mg/larvae/day) for black soldier fly larvae (BSFL)

\begin{tabular}{|c|c|c|c|c|c|c|}
\hline \multirow[t]{2}{*}{ Treatment regime $(\mathrm{kg})$} & \multicolumn{2}{|c|}{ Mean iron $(\mathrm{mg} / \mathrm{kg})$} & \multirow{2}{*}{$\begin{array}{l}\text { Removal effi- } \\
\text { ciency }(\%)\end{array}$} & \multirow{2}{*}{$\begin{array}{l}\text { Standard deviation } \\
(\mathrm{SD} \pm) \%\end{array}$} & \multirow{2}{*}{$\begin{array}{l}\text { Feeding rate (FR) } \\
\text { (mg/larvae/day) }\end{array}$} & \multirow[t]{2}{*}{$p$ values } \\
\hline & Substrate & $\overline{\text { Residue }}$ & & & & \\
\hline $\mathrm{T}-1(2.0 \mathrm{~kg})$ & 5.50 & 1.70 & 69.1 & \pm 2.7 & 71 & 0.04 \\
\hline $\mathrm{T}-2(2.5 \mathrm{~kg})$ & 3.40 & 1.90 & 44.1 & \pm 1.1 & 89 & 0.05 \\
\hline $\mathrm{T}-3(3.0 \mathrm{~kg})$ & 3.70 & 2.56 & 31.1 & \pm 0.8 & 105 & 0.04 \\
\hline $\mathrm{T}-4(3.5 \mathrm{~kg})$ & 5.30 & 2.48 & 53.2 & \pm 2.0 & 125 & 0.06 \\
\hline $\mathrm{T}-5(4.0 \mathrm{~kg})$ & 5.20 & 1.99 & 61.7 & \pm 2.3 & 143 & 0.07 \\
\hline Control (without larvae), $2.0 \mathrm{~kg}$ ) & 5.60 & 4.66 & 16.8 & \pm 0.7 & - & - \\
\hline
\end{tabular}

Treatment regime values in parenthesis ranging from 2.0 to $4.0 \mathrm{~kg}$ are the initial quantities of substrate. Values with $(P<0.05)$ were significantly different. The feeding rate (FR) was expressed as the total amount of organic waste given to 2000 larvae over a period of 14 days 
Table 8 Lead $(\mathrm{Pb})$

concentrations in the organic solid waste and in the compost obtained using different feeding rates ( $\mathrm{mg} / \mathrm{larvae} /$ day) for black soldier fly larvae (BSFL)

\begin{tabular}{|c|c|c|c|c|c|c|}
\hline \multirow[t]{2}{*}{ Treatment regime } & \multicolumn{2}{|c|}{ Mean lead (mg/kg) } & \multirow{2}{*}{$\begin{array}{l}\text { Removal effi- } \\
\text { ciency }(\%)\end{array}$} & \multirow{2}{*}{$\begin{array}{l}\text { Standard devia- } \\
\text { tion }(\mathrm{SD} \pm) \%\end{array}$} & \multirow{2}{*}{$\begin{array}{l}\text { Feeding rate (FR) } \\
\text { (mg/larvae/day) }\end{array}$} & \multirow[t]{2}{*}{$p$ values } \\
\hline & Substrate & Residue & & & & \\
\hline $\mathrm{T}-1(2.0 \mathrm{~kg})$ & 0.010 & 0.001 & 90.0 & \pm 6.6 & 71 & 0.03 \\
\hline $\mathrm{T}-2(2.5 \mathrm{~kg})$ & 0.010 & 0.001 & 90.0 & \pm 2.4 & 89 & 0.06 \\
\hline $\mathrm{T}-3(3.0 \mathrm{~kg})$ & 0.020 & 0.002 & 90.0 & \pm 2.9 & 105 & 0.04 \\
\hline $\mathrm{T}-4(3.5 \mathrm{~kg})$ & 0.010 & 0.002 & 80.0 & \pm 1.6 & 125 & 0.06 \\
\hline $\mathrm{T}-5(4.0 \mathrm{~kg})$ & 0.020 & 0.002 & 90.0 & \pm 2.4 & 143 & 0.06 \\
\hline $\begin{array}{r}\text { Control (without } \\
\text { larvae), } 2.0 \mathrm{~kg} \text { ) }\end{array}$ & 0.020 & 0.019 & 5.0 & \pm 1.6 & - & - \\
\hline
\end{tabular}

Treatment regime values in parenthesis ranging from 2.0 to $4.0 \mathrm{~kg}$ are the initial quantities of substrate. Values with $(P<0.05)$ were significantly different. The feeding rate $(\mathrm{FR})$ was expressed as the total amount of organic waste given to 2000 larvae over a period of 14 days
Tenebrionidae) discarded cells of the midgut epithelium after 4 days (Zurbrügg 2015). This assertion was consistent with the present study.

\section{Conclusions}

Under the circumstances of this experiment, the BSFL organic solid waste treatment technology could contribute to reducing the burden of organic fertilizers shortage in the farm market and provide new income opportunities for small-scale enterprise in developing countries. Furthermore, the compost quality fell within the standard quality in agriculture as a fertilizer. However, since there is cadmium accumulation in the last stage of the larvae (prepupae), it could limit the use of the prepupae in animal feeds. In the case of lead and arsenic, concerns about the use of prepupae in animal feed are less critical. Future research could take steps to evaluate possible bioaccumulation of heavy metals and toxics in the Hermetia illucens larvae before they are used as animal feedstock.

Acknowledgements The authors wish to thank the Department of Civil Engineering, KNUST, for hosting the site for the pilot project. Sincere thanks also go to the laboratory technicians for assisting in the olfactory challenging experiments and Mrs. Mabel Sarpong for linguistic editing support.

Open Access This article is distributed under the terms of the Creative Commons Attribution 4.0 International License (http://creativeco mmons.org/licenses/by/4.0/), which permits unrestricted use, distribution, and reproduction in any medium, provided you give appropriate credit to the original author(s) and the source, provide a link to the Creative Commons license, and indicate if changes were made.

\section{References}

Aja OC, Al-Kayiem HH (2014) Review of municipal solid waste management options in Malaysia, with an emphasis on sustainable waste-to-energy options. J Mater Cycles Waste 16(4):693-710. https://doi.org/10.1007/s10163-013-0220-z

Alvarez L (2012) The role of black soldier fly, Hermetia illucens (L.) (Diptera: Stratiomyidae) in sustainable waste management in Northern Climates. Dissertation, University of Windsor

Banks IJ (2014) To assess the impact of black soldier fly (Hermetia illucens) larvae on faecal reduction in pit latrines. Doctoral dissertation, London School of Hygiene \& Tropical Medicine

Banks IJ, Gibson WT, Cameron MM (2014) Growth rates of black soldier fly larvae fed on fresh human faeces and their implication for improving sanitation. Trop Med Int Health 19(1):14-22. https ://doi.org/10.1111/tmi.12228

Barry T (2004) Evaluation of the economic, social, and biological feasibility of bioconverting food wastes with the black soldier fly (Hermetia illucens). PhD Dissertation, University of Texas

Bernal MP, Alburquerque JA, Moral R (2009) Composting of animal manures and chemical criteria for compost maturity assessment. A review. Bioresour Technol 100(22):5444-5453. https://doi. org/10.1016/j.biortech.2008.11.027

Björnsson SF (2012) Aquafeed production from lower life forms. Preliminary process analysis of Single-Cell Protein and Black Soldier Fly Larvae production by converting organic waste to aquafeed ingredients. Doctoral dissertation, Master's Thesis. Aarhus University

Cammack J, Tomberlin J (2017) The impact of diet protein and carbohydrate on select life-history traits of the black soldier fly Hermetia illucens (L.) (Diptera: Stratiomyidae). Insects 8(2):56. https:// doi.org/10.3390/insects8020056

Charlton AJ, Dickinson M, Wakefield ME, Fitches E, Kenis M, Han R, Bruggeman G (2015) Exploring the chemical safety of fly larvae as a source of protein for animal feed. J Insects Food Feed $1(1): 7-16$

Deborah S, Raj JS (2016) Bioremediation of heavy metals from distilleries effluent using microbes. J Adv Res 1(2):23-28

Diener S, Solano NMS, Gutiérrez FR, Zurbrügg C, Tockner K (2011) Biological treatment of municipal organic waste using black soldier fly larvae. Waste Biomass Valori 2(4):357-363. https://doi. org/10.1007/s12649-011-9079-1

Diener S, Zurbrügg C, Tockner K (2015) Bioaccumulation of heavy metals in the black soldier fly, Hermetia illucens and effects on its life cycle. J Insects Food Feed 1(4):261-270. https://doi. org/10.3920/JIFF2015.0030 
Dominguez J, Edwards CA (2011) Relationships between composting and vermicomposting. Vermicult Technol Earthworms Org Wastes Environ Manage. https://doi.org/10.1201/b10453

Dortmans B (2015) Valorisation of organic waste-Effect of the feeding regime on process parameters in a continuous black soldier fly larvae composting system. Thesis. Department of Energy and Technology, Swedish University of Agricultural Sciences, Swedish

Gabler F, Vinnerås B (2014) Using black soldier fly for waste recycling and effective Salmonella spp. reduction. Thesis. Swedish University of Agricultural Sciences, Swedish

Hoornweg D, Bhada-Tata P (2012) What a waste: a global review of solid waste management, vol. 15. World Bank, Washington, DC

Jereb G (2004) Biodegradable Municipal Solid Waste Management. Nova Gorica, Polytechnic Nova Gorica, School of Environmental Sciences

Kim W, Bae S, Park K, Lee S, Choi Y, Han S, Koh Y (2011) Biochemical characterization of digestive enzymes in the black soldier fly, Hermetia illucens (Diptera: Stratiomyidae). J Asia Pac Entomol 14(1):11-14. https://doi.org/10.1016/j.aspen.2010.11.003

Lalander C, Diener S, Magri ME, Zurbrügg C, Lindström A, Vinnerås B (2013) Faecal sludge management with the larvae of the black soldier fly (Hermetia illucens). From a hygiene aspect. Sci Total Environ 458:312-318. https://doi.org/10.1016/j.scito tenv.2013.04.033

Lin-ki JWC (1975) Drift of Black-fly Larvae and the influence of watervelocity, substrate roughness and incident light intensity on their microdistribution (Diptera: Simuliidae). Doctoral Dissertation. MCMaster University

Mainoo NOK (2007) Feasibility of low cost vermicompost production in Accra, Ghana. Doctoral Dissertation, McGill University. https ://doi.org/10.15480/882.1112

Pan I, Dam B, Sen SK (2012) Composting of common organic wastes using microbial inoculants. 3 Biotech 2(2):127-134. https://doi. org/10.1007/s13205-011-0033-5

Polprasert C, Koottatep T (2007) Organic waste recycling. IWA publishing, London

Rana KM (2014) Development of black soldier fly larvae rearing technique to supplement fish feed. Doctoral Dissertation. Department of Aquaculture, Mymensingh, Bangladesh

Sarkar P, Chourasia R (2017) Bioconversion of organic solid wastes into biofortified compost using a microbial consortium. Int J Recycl Org Waste Agric 6(4):321-334. https://doi.org/10.1007/ s40093-017-0180-8

Sarpong D, Kwarteng SO, Gyasi SF, Buamah R, Donkor E, Botchway EY, Acquah S (2018) Biodegradation of heterogeneous mixture of organic fraction of municipal solid waste by black soldier fly larvae (Hermetia illucens) under the tropical climate conditions. Int J Innov Res Sci Eng Technol 5(4):1-11

Tirado SM (2008) Effects of turning frequency, pile size and season on physical, chemical and biological properties during composting of dairy manure/sawdust $(\mathrm{dm}+\mathrm{s})$. Doctoral Dissertation, The Ohio State University

Tomberlin JK, Sheppard DC, Joyce JA (2002) Selected life-history traits of black soldier flies (Diptera: Stratiomyidae) reared on three artificial diets. Ann Entomol Soc Am 95(3):379-386. https://doi. org/10.1603/0013-8746(2002)095[0379:SLHTOB]2.0.CO;2

Un-Habitat United Nations Human Settlements Programme (2010) Solid waste management in the world's cities: water and sanitation in the world's cities 2010. UN-HABITAT. https://doi.org/10.1146/ annurev-environ-050511-122532

Van der Fels-Klerx HJ, Camenzuli L, Van Der Lee MK, Oonincx DGAB (2016) Uptake of cadmium, lead and arsenic by Tenebrio molitor and Hermetia illucens from contaminated substrates. PLoS One 11(11):e0166186

Verma S (2002) Anaerobic digestion of biodegradable organics in municipal solid wastes. Department of Earth \& Environmental Engineering. Fu Foundation School of Engineering and Applied Science, Columbia University, New York

Wang YS, Shelomi M (2017) Review of black soldier fly (Hermetia illucens) as animal feed and human food. Foods 6(10):91. https:// doi.org/10.3390/foods6100091

Wei Z, Xi B, Zhao Y, Wang S, Liu H, Jiang Y (2007) Effect of inoculating microbes in municipal solid waste composting on characteristics of humic acid. Chemosphere 68(2):368-374. https://doi. org/10.1016/j.chemosphere.2006.12.067

Zhao YR, Liu TJ, Chen XS, Xie Q, Huang LP (2016) The effect of temperature on the biodegradation properties of municipal solid waste. Waste Manag Res. 34(3):265-274. https://doi. org/10.1177/0734242X15622811

Zurbrügg C (2015) Bioaccumulation of heavy metals in the black soldier fly, Hermetia illucens and effects on its life cycle. J Insects Food Feed 1(4):261-270. https://doi.org/10.3920/JIFF2015.0030

Publisher's Note Springer Nature remains neutral with regard to jurisdictional claims in published maps and institutional affiliations. 